\title{
Changes in Concept of the European Policy of Roma Integration
}

\author{
HAID Tibor ${ }^{1}$
}

\begin{abstract}
The success of the social integration of the Gipsy population is one of the basic con-ditions of the common European future. However, the direction of the efforts has been proved to be maladjusted. For being able to concentrate the resources restricted by the economic crises, a modification of concept has been deeply needed. Instead of focusing on anti-discrimination policy, the areas of a real effective governmental intervention must be determined. Elaborating the framework of the common European Integration Strategy of Gypsies, the Hungarian presidency aimed rather at social and educational issues, which gave a sign of a new approach to the topic.
\end{abstract}

Keywords: anti-discrimination, changing of concept, Gypsy/Roma, integration, strategic framework

\section{Introduction}

The actual economic and financial crisis has brought to light, one by one, the internal contradic- tions threatening the European union and their explosion. A thorough and consequential examina- tion of this phenomenon points to the same deficiency. The alliance of the european states origi- nally established as an economic organization has been widening and deepening with the joining of new member states. Although the cooperation has become more and more tight and close, it has also revealed the question of the social legitimacy of this widening common regulatory body. The accelerated enlargement of the union has resulted in the incorporation of societies which are divided by social tension not known in the original "core" member-states before, and which differ from the original Western European member states in regards to historical background, economic capacities and social identity as well.

The process of integration having just started after the enlargement seems to halt or even to stop forever because of the crises. But the main reason for this stop in the procedure of integration is not the shrinking amount of the allocated financial support. This factor might have sped up this break down, and has also made it impossible to delay facing and estimating the deficiencies of the base of the union which are mainly not economic but rather moral and cultural by nature, and have been swept under the carpet before the crises.

The harsh debates during the slow process of the elaboration and promulgation of the Com- mon European Constitution already revealed - even at the level of political declaration - the lack of common cohesive values (with the exception the old glue composed of some partial but still strong common economic interests), and which mental factors are stipulated to be the base of inte- gration in the social sub-systems. However, it seems to be evident that the European union should cooperate in a closer and more efficient way. However the commonly accepted ideal figure of the

1 Email: haid.tibor@chello.hu

European Citizen, the ideal individual that is supposed to make the common economy function and prosper has not appeared yet. But without a common European identity, a long-term cooperation is impossible. On the one hand, it seems to be unimaginable to have a system of reallocation that supports and is advantageous and satisfactory for all participants. The highly intensive cooperation needed to become economically competitive also involves the partial delegation of some factors of national sovereignty by the member states to the common bodies and organs of the union. This legal action can not purely derive from the actually coinciding economic interests of the member states. On the other hand, only those societies can survive the periodically appearing economic cri- ses without the risk of disintegration, which possess a common moral creed. This social treasure is necessarily based on the impression of community, in our case it slould be the common European identity.

Studying the situation of the Gypsies who are estimated as the most numerous ethnic minority group within the boundaries of the European union, the lack of the common European identity is so evidently visual that the phenomenon even poses doubt as to the possible success of the actions aiming to found a mental base of the alliance at any time in the future. It is difficult to assert that the Gypsies - whose first groups were noticed present in the Balkans as early as the beginning of the $11^{\text {th }}$ century and by the $15^{\text {th }}$ century arrived in the central areas of the continent - should not be as at home in the European present and past as any other nation looking back with a thousand- year-old presence here. Nevertheless, they are still surrounded by an atmosphere of being odd or even alien, and if numerous groups of them appear somewhere they usually raise irrational fears among their hosts.

you can easily get the well prepared and ready to use ideological explanations for the reasons of this phenomenon on the market of intellectual products. In the main stream, the problem seems to derive from the original sin of approaching with 
Haid Tibor: Changes in the concept of the European policy of roma-integration

preconceptions. Nowadays the more refined ver- sion of the doctrine - blaming the stereotyped mindset for the majority of social problems - is also available. The key word "prejudice or stereotype" has not lost its shine but it is not necessarily the exclusive possession of the majority any more, a minority group can also have prejudices against other social groups as well. The idea of blaming prejudice does not consider the fact that there is no alternative way of thinking which does not contain the stereotyped approach of getting knowl- edge, and can be followed by the vast majority of the society. Human cognitive activity is restricted both in time and in space. But the interest stimulating us to gather knowledge about our social and natural surrounding also urges us to close the contemplative phase as soon as possible with a prac- tically useable outcome. So in a nutshell, the majority society rarely gets information just for being curious, without keeping a specific - not surely known - aim in mind, but we want to find the com- mon rules of mechanism which function or - talking about social phenomena - motivate the huge diversity of experience and actions (behaviours). We are eager to know "what makes the world go round" and use the rule in our personal life, for our own interest. And we share what we have gained according to our familiar, social, ethnic, religious, professional etc. connections to help our group-mates to spare the time and energy of searching and studying on their own. And we are mutually keen on accepting the rules defined by other individuals and credible people especially the rules supported by some little pieces of personal experience - rather than choosing the odd and tiring way of creating new ones. Accepting the rules provides us comfort and the atmosphere of safety, sharing those works as a cohesive factor in the group and helps the members to cooperate.

Those who follow the doctrine of blaming prejudice normally do not consider that the common opinion derived from generalised experience that becomes a part of tradition can only be deprived of its acceptance by individually felt experiences which are strong enough to destroy the contrast-

ing previous opinion and even to make the individual share the changed idea. But automatic refusal of the conclusions drawn and generalised from real experience - or even the direct or indirect re- prisal of the publication of these conclusions - leads to superficial adaptations of the main stream and hides the real opinion. ${ }^{2}$ The manner of scourging the common opinion of the social majority because of its prejudice also sends the message that instead of drawing the conclusions of experi- ence you should accept in public only the ideas of the main stream intellectuals, otherwise those who confess their different opinion will lose their credibility, risk the possibility for publication and finally find themselves at the periphery of public life.

The view detailed above dominates public opinion, even nowadays; it is rather counter-pro- ductive. On the one hand it produces frustration by forcing people to accept the ruling intellectual opinion, even in those cases when it contrasts with the result of the evaluation of personal expe- rience. Speaking out on social problems sincerely in public is usually the first step on the way to solving them. If you feel deprived constantly of this possibility, it usually arouses indifference or even hatred against the whole topic, without any distinction among the social group protected by the muzzle of political correctness.

On the other hand, it gives the unique taste of "forbidden fruit" to the other old and wide-spread common opinion, which is quite different in its attitude but not less dogmatic in its approach, de- picting Gypsies mainly as the source of many social problems. The evident difficulties in social integration of this minority group are explained by their unchangeable character and behaviour ${ }^{3}$, leading to the conclusion that supporting their integration is only a waste of time, money and effort. Consequently, measures at a societal level should not be made for them, but against their effect, as a social self-defending activity for the interest of the majority.

The source of the theory of the unchangeable character of certain ethnic groups can be dis- closed in the school of thought of Social-Darwinism, which appeared as one of the most modern approaches to understand the different level of human civilizations, applying the idea of evolution to the social sciences, and also as an optimistic justification of the white intrusion into the less (or un-) developed parts of the world with a mission of spreading the benefits of Western civilization.

Both the supercilious snobbism of social engineering, which detects only primitive prejudice in the fears and antipathy of the majority of the society, and the opposing effort to form an identity out of these negative experiences, fears and contradictions, evoke the image of "bilateral social behaviour" described by István Bibó, already in 1949. as they are "totally dehumanized because they are based on nightmares or survived hurts and sufferings, or unjustifiable feeling of honour and rank, or causeless inferiority complex." ${ }^{4}$ Both attitudes detailed have a lifeless dogmatism as a common alienating feature, so both of them affect harmfully the minority group and its relationship with the other parts of the society.

We should regard the minority issue in the European union and the above mentioned opposing attitudes as the spiritual background to when the first groups of Central and South eastern euro- pean Gypsy immigrants appeared in the West, in the years just before the enlargement of 2004. Searching for some residuary advantages of the welfsire state, on the wane, they also made the core part of europe face the deficiencies and doubts of its basic values. Several campaigns have been launched based on previous social surveys since the historic enlargement of 2004. But the success

2 More details can be found about the hiding of opinion in: SZABó (2008)

3 According to the survey conducted in the first decade of 2000's, it seemed to be firmly widely accepted that Gypsies are not able to follow the general social ways of life because of their "genetically coded different manners". GyIMESy-NAGy (2008)

4 SZABó (2004) p. 240

seems to be delayed. One of the clues for breaking through is the reconsideration of the concept and practice of basic human rights with a new approach of minority and anti-discrimination pol- icy. The economic crises that reached the union by 2009 made it clear for the vast majority of the European citizens that the whole concept of the welfare state has been deeply 
Haid Tibor: Changes in the concept of the European policy of roma-integration

involved in the crises. The price of social peace could not even be paid by social support and allocations, if the enlargement had not meant also the arrival of economic immigrants from the new member states and all the social tension caused by them. But the enlargement and the crises soon afterward urged the elaboration of a new concept of social division of labour and the individual rights and obliga- tions, to rethink the idea and practice of positive discrimination with a regard to its collateral social and economic effects, to find a new balance between the individual and collective identity, and to restore the role of state in the public opinion.

As Gypsies are a numerous minority group that consist of linguistically and ethnically hetero- genic subgroups, whose problems of identity are closely related to their existential disadvantages, the Union cannot avoid or delay finding a solution for their integration. But it opens another previ- ous question that has not been solved yet, the lack of a common European identity. As integration of a group of people means finding a suitable place in a larger unity, the first step on this way must be the identification of the unity you are going to be incorporated in to.

The factual presence of Gypsies in Western Europe unwilling to return to the "backyard of the continent" where most of them are from, might catalyse the necessary changing of concepts detailed above even after the end of economic crises.

\section{Gypsies $^{5}$ in an enlarged Europe}

$80 \%$ of the 10-12 million Gypsies living in the European union have arrived in the area and also in the focus of the media since 2004. Mentioning their name evokes a string of associations and worries normally ending in doubts regarding the sustainability of the common European future even among the non-eurosceptic citizens of the states that have been Eumembers since before

2004. Their simple presence usually works as an evident but not directly uttered argument against any enlargement to the East or South-East in the future.

The problem is not new at all. Just remember the loud echo in the media made by the Gypsy emigrants from Hungary ("romas from Zámoly"), Slovakia and the Czech republic arriving in the West before 2004. The decision-makers, on the extending of the geographical boundaries of the union, must have been alerted by these events to be able to estimate the depth of the social gap be- tween the core part of the continent and the post-communist candidate-states, as well as the weight of the new type of problems - within the ones caused by the existential and social disadvantages of the Gypsy population - that arrived together with the historic enlargement.

Between 29th June $-1^{\text {st }}$ July 2003. a regional conference took place in Budapest with the title

: "romas in an enlarging Europe. The challenges of the Future". The meeting of the heads of state or government of Bulgaria, Croatia, Czech republic, Macedonia, romania, Serbia (together with Crna Gora - Montenegro at this time), Slovakia, and Hungary as the host country, was organised

5 Here I would like to explain why I use the world "Gypsy" instead of roma, romi...First of all, possessing one's own name, used by the surrounding nation means a certain level of acceptance, or at least a long coexistence. using

a self nomination instead of avoiding some unpleasant connotations or associations also deprives this minority of the atmosphere of being a tome in the language. I should also note, that the word rOM, rOMI, rOMA is not generally accepted among the Hungarian Gypsies, as the most numerous group of them, the only Hungarian-speaking Gypsies, do not define themselves as Roma, but Gypsy or Romungro.

by the Institution of Open Society and the World Bank. The participants declared the 10-year-peri- od 2005-2015 as the Decade of roma Inclusion.

At the sessions on $16^{\text {th }}$ November 2004, held in Budapest the participants accepted and signed the Declaration of the Decade of roma Inclusion, aiming to stop the discrimination of romas and to surmount the social gap between them and the other parts of the societies. They planned to achieve these goals by studying and analysing the experience gained during the realisation of the Action Plan for the Decade, with the assistance of Gypsy communities and by the initiation of other states in the project. In Sofia on $2^{\text {nd }}$ February 2005. the Programme of the Decade of roma Inclu- sion (hereinafter: PDRI) was officially launched with ceremonies. The PDRI was promulgated in Hungary on $19^{\text {th }}$ May 2005.

The PDrI links the aim of social and economic integration of Gypsies with the purpose of advocat- ing a more positive public opinion about them. The participant countries elaborate their own national roma Strategy coordinating the commonly accepted aims

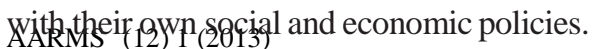

52

The participant states of PDrI have two direct obligations. Each of them is bound to elaborate a national action plan as a schedule of the realisation of the national strategic plan that can be con- sidered the state-level application of PDrI. The action plans have 4 common features following the 4 areas of priority of PDrI: all of them must focus on education, health care, employment and dwelling (habitation). They also target to initiate as many members of the Gypsy intelligentsia as possible, both at the level of planning and realisation. The other obligation is establishing a mon- itoring system to follow the execution of action plans by gathering, analysing and forwarding the relevant data and information. The monitoring system can also function as a tool to re-plan the route and even to modify the destination.

\section{The year of Hungary in the presidency of PDRI}

Hungary assumed the presidency of PDrI on $1^{\text {st }}$ July 2007 for a year. Erecting its priorities, the 
Haid Tibor: Changes in the concept of the European policy of roma-integration

Hungarian leadership could use the experience of the previous Bulgarian period of the presidency.

Keeping in mind the acceleration of the process of enlargement of the union and also the constant presence of Eastern European Gypsies in the Western member states, the Hungarian pres- idency wanted to increase the number of member states of PDrI, inviting Bosnia, Moldavia, Por- tugal, Spain, and Slovenia into the framework of PDrI-cooperation. Hungary also initiated that the common institutions and bodies of the union put into their schedule the discussion of PDrI with the aim of elaborating a unified european Roma Strategy.

The Hungarian presidency also emphasized the importance of corporate social responsibility (here in after: CSr) as a new priority of PDrI. They also launched a communication campaign to inform the vast majority of European societies about the living conditions of Gypsies. They estab- lished some groups of experts with the task of finding possible solutions to eliminate the segregation of Gypsies in the areas of dwelling and education. Finally, the Hungarian presidency also wanted to develop the monitoring system introduced by the previous Bulgarian period of leadership.

The CSr-concept is based on the idea that the actors of the economy voluntarily incorporate some social and environmental values and approaches in their business policy and that they even represent this towards their partners. According to the CSr-idea companies are supposed to realise that the social and environmental side-effects of economic activity risk sustainable development, so - following their long term interests in business - they voluntarily adjust their mindset from the points of view originally incompatible with the narrow way of thinking of a competitive market economy, otherwise the whole social and economic system will collapse, burying the market where

they gain their profit. The CSR-concept also supposes that the idea of sustainable development has already been accepted by the vast social majority; consequently the additional costs of CSr-ac-tivities should also recovered in the short term because of the Pr-advantages that companies with positive and responsible social and environmental attitude would gain.

The Hungarian presidency raised the CSr-issue regarding the roma Inclusion. Companies might start up a system of scholarships with the aim of eliminating the disparity of qualifications of Gypsies, involving long-term educational programs for adults who dropped out of public ele- mentary education and also short-term training for those who have basic skills but still need a more market orientated qualification. The theoreticians of CSR also suggest inserting some methods of direct or indirect positive discrimination in the field of employment. Providing better chances for Gypsy candidates for a job is an example for the first item, as supporting legal consulting offices granted the minority a way of indirect positive discrimination. As a part of CSr, the élite of busi- ness life are supposed to support roma inclusion by sponsoring cultural events and by making Gypsies appear in a positive light - as the "good guys" - in advertisements. All of these were planned to be a part of comprehensive national CSr-strategies.

During the Hungarian presidency the issue of a Common European roma Strategy was pro- pounded. The common strategy was planned to be a good tool for the more efficient enforcement of interests, a higher efficacy of sponsored social programmes, a solution for the problems of economic migration and also for accelerating the social integration of Gypsies. The theoreticians pointed to the poverty, the uncertain view of the future and discrimination as the reasons for the economic migration. They marked as patterns those that still exist in European frame strategies of anti-discrimination regarding the inequality of sexes, handicapped people or immigrants.

The Hungarian presidency put the policy of anti-segregation in the central position of the frame strategy, because it was considered a way of avoiding the conservation of the multiple disadvan- tages of Gypsies in the area of education and accommodation.

Segregation in dwelling means partly undeveloped districts with low level and crowded living conditions - ghettos within the boundaries of a community, and it can also appear at regional level, as in the areas of slow (or no) economic improvement, where the ethnic proportions of the population normally change dramatically, resulting in permanent or even deepening disadvantages in infrastructure and employment. The elimination of segregation in the area of accommodation was mainly hoped from the success of proposed programs of building social tenement-dwellings but it was also combined with other integrative programs in the field of education and employment.

As well as in the area of dwelling, the segregation in education appears in different levels from special Gypsy-classes within the same school, to schools exclusively for Gypsies and non-Gypsies. To discontinue the practice of segregation in the field of education, the Hungarian presidency pro- posed to introduce pedagogical programs for developing the abilities of pupils, widen the chances for further studies and try to decrease the tendency of dropping out of the school system after basic education

AARMÄni(shed.(2Why also planned to elaborate a pedagogical framework of unified and com- prehensive standards and methods with the aim of discontinuing educational segregation.

Both for advertising the European roma Strategy and for achieving its goals a communication strategy was highly needed. reaching the decision-makers, media-experts and the youth between

18-35 as the target groups was the strategy, the theoreticians wanted to influence the whole of society, to make it accept the existence of PDrI and also to make them change their opinion and attitude regarding Gypsies in a more positive direction.

\section{The frist traces of coceptinal changes in European roma inclusion policy}

By the time Hungary took over the presidential duties of the union on $1^{\text {st }}$ January 2011, it had already been clarified that the measures and plans introduced in the hope of enhancing the inte- gration of Gypsies had not brought enough results. The 
Haid Tibor: Changes in the concept of the European policy of roma-integration

riots of starvation in Eastern Slovakia in

2008-2009 already had a quite strong ethnic feature, and a string of criminal cases in Hungary at the same time was even more closely related to both the victims' and the committers' ethnic origin. Just remember the case at Olaszliszka, another murder in Veszprém committed by Gypsies, and the series of violent crime - mainly murders - against Gypsies, in both groups of cases the perpetrators were intensively motivated by ethnic reasons. It became evident for the vast majority of Eastern European citizens, that the ethnic tension partly deriving from the economic-existential situation was leaving the well known path of crimes against property.

In the autumn of 2010, in France, authorities had to close down illegal Gypsy settlements. As the procedure took place in the cradle of European democracy, it caused great media-excitement and made the intellectuals reopen the tin of ideas stored since the arrival of Gypsies from Zámoly to Strassbourg. But it was felt, for the first time that something had already changed in the public opinion regarding the minority issue. Now the determined and firm - but not cruel, nor antihuman - governmental measures were followed by sympathy and met the expectations of the majority of the French, only a loud minority were crying the wolf call of racism. ${ }^{6}$

Since the phenomenon was strongly related to economic migration and effected the whole union - within the more influential core-member-states - the european community urged the Hun- garian presidency to find a quick and effective solution. Hungary, which as a country has a lot of experience of both coexistence with a relatively numerous Gypsy population and also state spon- sored measures (positive and negative as well) ${ }^{7}$, had to elaborate the basic principles and frame- work of the new common European roma inclusion plan, the European roma Strategy.

After the precedents detailed above, the European Commission accepted on $5^{\text {th }}$ April 2011 its Communication (here in after: Communication) as the European union framework for national roma integration strategies up to 2020.

The Communication declares that improving the situation of the Gypsy population is a social and economic imperative both for the union and its member states. It also stated that the 10-12 million roma population facing prejudice, intolerance and discrimination live in very poor so- cio-economic conditions, which is not tolerable in the union at the beginning of the $21^{\text {st }}$ century.

According to the Communication, the elimination of their marginalisation is a part of the Eu- rope 2020 strategy, which is described as a basic plan for a new growth path. It is very important to emphasize as evidence of a change in concept that according to the Communication the social and economic integration is a two-way process, urging both the majority of the population and also the Gypsies to change their mindsets.

The Communication outlines the primary responsibility of the public authorities of member states for the measures needed to eliminate discrimination and to provide the necessary condi- tions for the practical realisation of equality before the law. But - as another trace of the change

6 The Hungarian Kossuth radio broadcast a discussion with interpretation between Arnaud Montebourg - who wanted to emphasize the racist character of governmental measures - and Pierre Lellouche - the minister of European affairs and Brice Hortefoux - the minister of internal affairs - on 20th January 2011 in the program "Jelfogó". The simple sentence of Pierre Lellouche : "A free airplane ticket home, to another union member state and the transportation to the gas-chambers have absolutely nothing in common" sounded like a real ideological breakthrough.

7 BÁrSONy (1997) p. 319-332.

of concept - positive discrimination cannot be found as an obligatory practice of the states. So in a nutshell, the key is a world of equality and anti-discrimination but not positive discrimination, which is a significant modification of approach. The document also calls the attention to another change pointing to the potential economic advantages of integrating Gypsies into the labour mar- ket. Instead of claiming social assistance they would pay tax from their income, a fact which itself can strengthen the social cohesion between this minority groups and the majority of the society.

The Communication mentions that efforts have already been made both by the member states and the union, but outlines that - in spite of them - only little has changed in the daily life of Gyp- sies. Thatis why the document urges the member states to adjust their roma integration strategy to the Eu framework, and also harmonise the roma integration polices with other strategies against poverty and exclusion. This new concept is supposed to increase the effectiveness of national roma integration strategies and also diminish the indirect discriminative effect, not excluding other groups suffering from poverty, inequality and exclusion.

AARMS The ${ }_{(12)}$ Commynication sets the main goals of the roma integration, which are quite similar r $_{4}$ to the ones of PDrI. These are the access to education, employment, healthcare and housing and essential services.

Among these crucial areas the Communication mainly deals with the goal of access to edu- cation, underlining the minimum aim ensuring that all roma children complete at least primary school. The document also emphasizes the importance of eliminating segregation and other forms of discrimination in education. As a new element, for those who are still above the compulsory school-age but have dropped out of primary school without having finished, the document encourages "second chance programs" for enabling young adults without a complete primary education to get this minimum qualification, enabling them to enter into the labour market or even further education. It also highlights the importance of participation in early childhood education and care as a tool for overcoming the educational disadvantage. For achieving these goals the Communica- tion underlines the key role of churches, religious associations and school mediators who can help Gypsy parents in understanding the importance of organised education. Mediators should advise parents on the local education system and help children in the transition between each stage of their school carrier. This kind of mediation is 
Haid Tibor: Changes in the concept of the European policy of roma-integration

especially important for non-sedentary Gypsy children. As a part of this two-way process, the document urges reform of teachers' training curricula and to elaborate innovative teaching methods for enabling teachers to tackle the special needs and diffi- culties which they may face.

Regarding the access to employment, the Communication underlines the significant gap be- tween the employment rate for Gypsies and the rest of the population. To reduce it, the document suggests granting Gypsies full access to vocational training and - after getting the needed qualifi- cation - to the job market, in a non-discriminatory way. In terms of education, there are two other methods mentioned. On the one hand, a micro-credit system the self-employment should be en- couraged, on the other hand in the public sector qualified Gypsy civil servants should be employed, if it is possible.

In the field of healthcare there is a significant disadvantage suffered by Gypsies, which is clearly reflected by their life expectancy being 10 years less than the majority and a much higher child mortality than the general population. The Communication denotes many reasons for it, one of them is discrimination in the access to healthcare. But the others - poor living conditions, lower presence in information campaigns, exposure to higher health risks - seems to have more importance. In linking the Gypsy population to the healthcare system and encouraging them to more frequently have - partly preventive - visits, qualified Gypsies have a key role.

regarding dwelling, the Communication emphasizes the much poorer access to public utilities (water, electricity, gas). There is the special problem of non-sedentary Gypsies who rarely find sites with enough access to water. The suggested solution of the problem is promoting non-discrimi- natory access to social housing and also special attention to the needs of non-sedentary Gypsies.

The Communication urges member states to elaborate comprehensive and coordinated strate- gies of roma integration on the base of clear policy commitments regarding the four areas men- tioned and detailed above. Therefore the member states should:

- set achievable goals in the four areas of priority with realistic minimum standards,

- identify the most disadvantaged regions and segregated areas,

- allocate funding from national budgets, which can be completed by international and union support

- introduce and apply an effective monitoring system to evaluate the needs and achievements

- build up a system of close cooperation and dialogue with Gypsy civil society, regional author- ities and non-governmental organisation, churches involved in the issue.

The Communication emphasizes the responsibility of member states, but also urges them to involve competent civil organisations and churches with relevant information on the needs and a living relationship with Gypsy communities. With their help public administration can spare the task of detecting the problems.

The Communication combines roma integration with the possible further enlargement of the European union, pointing to the 3.8 million of Gypsies living in Turkey and in the Western Bal- kans even among poorer conditions than the roma population of member states. The development of their socio-economic situation is an important issue of the negotiations in the joining procedure.

The Communication declares the leading role of the Commission in roma integration, and especially points to the importance of an efficient monitoring system. The Communication ends with an ambitious and imperative conclusion: the situation of the roma population must change significantly within 10 years.

\section{Conclusion}

In comparing PDrI and the Communication the change in concept of roma integration seems to be clear. The most important feature of the modified approach is that the policy for the integration of Gypsies has become a common issue for the whole union as one of the highest priorities. It reached an elaborate program which does not exclusively involve the participant states of PDrI where the majority of Gypsies are from.

It is a not a less important achievement that the Communication underlines the Gypsies' own responsibility regarding their integration, leaving behind the one-sided previous approach focusing on mainly anti-discrimination policy.

Giving up the CSr-concept belongs to a wider and deeper change in the perception of the role of the state and nongovernmental and non-profit organisations. The idea of optimal auto-regula- tion by the actors of the market economy

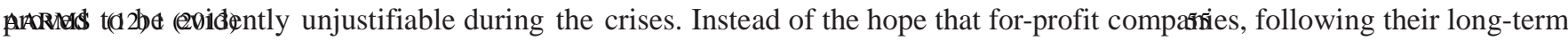
interests, would effectively regulate economic or even social issues, the urgent need of regulating the market and its actors by the state has become evident. But not only the role of the state - as the most powerful non-profit social organisation -, but also the non-profit civil organisations and churches must be reactivated, because of their original non-profit, non-competitive mindset and approach. There is no reason to be scared of their ideological or religious message either.

Finally, the freshest innovation of the Communication is that it deals with roma integration as a core but not unique part of a bigger social problem, namely the fight against poverty and discrim- ination in any terms. I suppose that this approach suits more the complexity of roma integration because it does not address the question of assimilation and ethnic identity. As the Gypsy popu- lation is not only the most numerous but also the most heterogenic ethnic minority group in the European union, a common European roma integration 
strategy cannot be effective if it focuses on this question which is an internal affair of this ethnic group and might be answered differently by each subgroup of Gypsies. restricting the area of activity of public administration to more practical issues is a more realistic approach with more achievable goals.

\section{References}

BALOGH András - rOSTOVÁNyI Zsolt - Búr Gábor - ANDErLE Ádám (2002): Nemzet és nacionalizmus, Ázsia, Afrika, Latin-Amerika. Korona Kiadó Budapest.

BÁrSONy János (1997): A cigányság és a rendőrség kapcsolatának történelmi összefüggései. Szöveggyüjtemény a kisebbségi ügyek rendőrségi kezeléséhez. COLPI, Budapest.

BErNÁTH Gábor (2004): Kitaposott utak. esélyek és esélyegyenlőtlenségek. In: Társadalom és Honvédelem. Vol. VIII. No. 1-2. (roma Special Issue) ZMNE. p. 86-104.

HetiVálasz: Nem szokta a cigány (Földprogram - sikerverejtékkel). 14 April, 2011 (Vol. XI. No. 15.) GyIMESI Gyula

- NAGy Kálmán (2008): Vélekedések a cigány katonákról. In: Társadalom és Honvédelem. Vol. XII. No. 1. (roma Special Issue) ZMNE. p. 124-137.

A Magyar elnökség programja 2007. július 1-2008. június 30. Magyar Köztársaság Szociális és Munk- aügyi Minisztériuma, Budapest, 2007.

SZABó A. Ferenc (2004): roma migráció. In: Társadalom és Honvédelem. Vol. VIII. No. 1-2. (roma Special Issue) ZMNE. p. 237-241.

SZABó János (2008): Romák a haderőben In: Társadalom és Honvédelem. Vol. XII. No. 1. (roma Spe- cial Issue) ZMNE. p. 124-137.

TóTH Sándor (2004): A magyarországi cigányság a társadalom tudományi kutatások tükrében. In: Társadalom és Honvédelem. Vol. VIII. No. 1-2. (roma Special Issue) ZMNE. p. 214-236. 